\title{
Lifestyle Migration in South Sinai, Egypt: Nationalisation, Privileged Citizenship and Indigenous Rights
}

\author{
Nadeem KARKABI \\ SOAS, University of London
}

\begin{abstract}
The South Sinai region in Egypt has been a politically disputed borderland. After three decades, it was transformed to a tourist area and, in recent years, seen the development of residential settlements as well. This paper will explore how European lifestyle migrants and indigenous Bedouins negotiate civil membership vis-à-vis the Egyptian state in the tourist coastal towns in the area. It will discuss the implementation of governmental policies to nationalise South Sinai, on the one hand, and the establishment of civic spaces operating on free global market basis in order to achieve financial development, on the other. The contradiction between these two processes created a situation where a group of foreign migrants was allowed privileged rights, whereas indigenous Bedouins were collectively marginalised. By relating to policies regarding property ownership and accommodation of lifestyle migration, I will discuss how the Egyptian government allowed not only individual inequality, but also a categorical difference, to prevail based on tribal affiliation and financial qualifications away from national belonging. The violation of the sensitive equilibrium operating within the frames of the modern nation-state, between the idea of national community with equal rights and that of free economic rights to individual property, has created a threat to the Egyptian state as a governing authority.
\end{abstract}

Keywords: citizenship, civil participation, indigenous rights, lifestyle migration, property, South Sinai.

Increased global mobility of various populations unravels the explicit connection between the notions of citizenship, civil participation, and national belonging. New liberal rhetoric of universal individual rights as well as communitarian rhetoric of differential collective affiliations are shaping the claims of migrant groups in Western democracies for political and civil entitlements. These tendencies have recently begun expanding to privileged

e-mail: n_karkabi@soas.ac.uk. This is the place to express my deep gratitude to the people of South Sinai, and especially Dahab, whose kind hospitality and invaluable help makes me always feel at home. I thank Maureen Pritchard, Itamar Shahar and Sergei Gornosteiv for their useful comments on previous drafts. My appreciation must go to Parvathi Raman as well as to Smadar Lavie for supporting my research in Sinai. I am especially grateful to Riva Joffe for her time and effort to proofread and remark on my work. 
migrants from affluent countries settling down in dependant countries of the global South without holding the local nationality. This new pattern of migration has led to civil participation of migrants, based only on economic capacities, and is questioning the civil and political exclusion of indigenous minorities by nation-states.

In the last three decades, these global processes were significant in shaping the social reality of the South Sinai region in Egypt. This region has been transformed from a politically disputed borderland to a tourist area and, more recently, seen the development of residential settlements as well. The political and economic changes in South Sinai have urged the indigenous Bedouin nomads into urbanisation. Moreover, it has introduced new populations into the coastal towns in the region; with the governmental resettlement of Egyptian citizens from the mainland and the lifestyle migration of Europeans seeking warm climate and inexpensive cost of living.

This paper will explore how European lifestyle migrants and indigenous Bedouins negotiate civil membership vis-à-vis the Egyptian state in the tourist coastal towns of South Sinai. In order to examine such matters the article will address property ownership and alternative community formations based on financial capacities and tribal affiliations. The claim of property ownership and land registration according to the civil law prominently demonstrates the power relations in the aforementioned social reality. The contest over land rights is carried out at first through the transition from Bedouin customary law to the state civil system. Thus, through the efforts of the Egyptian government to nationalise the Sinai Peninsula, official state registry of the land becomes a structural practice of discrimination. Furthermore, caught in between limiting foreigners' rights to ownership of property and keeping investments flowing into the country, the national government is put in a complex situation where its political and financial interests are put in contradiction. This has urged the Egyptian government to grant a special status to the Sinai touristic towns, in which policies of financial privilege and political discrimination in civil membership challenge the promise of national equal citizenship rights and the efficiency of the nation-state.

Examining this social reality becomes especially relevant after the recent political changes in Egypt and with the aspirations of the people to participate in civil and political life in the country. So far the influences of the freshly elected political institutions on South Sinai are not clear. Therefore, the accounts in this paper will relate mainly to the governmental policies in South Sinai during the former presidency period of Hosni Mubarak.

This article is based on several short-term fieldwork trips to the area from 2006 to 2010. The research included participant observation in the touristic areas of Dahab and Sharm El-Sheik. In addition semi-structured interviews and informal conversations were conducted with Bedouin, European and Egyptian residents of these towns. Given the great mobility of all three groups, I chose to focus on individuals who have been living most of the year and for a period of at least five consequential years 
in the area. Particular attention was given to regulation of property rights, from both the civil state legal system and the Bedouin customary law. Supplementary data in this paper draws upon archival survey of written material of journalism articles from Egyptian and international online newspapers, as well as Egyptian state documents and NGOs' reports published between 1990 and 2012.

\section{Lifestyle Migration to the Global South: Privilege, Consumption and the Influence on Local Populations}

Tourism, as a genre of global consumption for affluent people, has become the foundation for new forms of migration, described as 'tourism migration' (Williams and Hall, 2002) or 'leisure migration' (Böröcz, 1996). This has built up gradually, starting with seasonal migration of retired populations from Northern and Central Europe as well as North America, who spent their winters in Southern countries in pursuit of a better climate (Warnes and Williams, 2006). Spain and Mexico were favourite destinations; there migrants purchased property thereby introducing the well-studied phenomenon of international 'second homes' (Hall and Muller, 2004). On the other hand, young backpackers also began working in tourist destinations to finance their extended trips around the world (Loker-Murphy and Pierce, 1995). Travel and communication infrastructure improved, whereas dissatisfaction with social life and employment in their home countries increased. These encouraged other groups to join the global flow of tourism migration in pursuit of a better lifestyle.

What later came to be known as 'lifestyle migration' (Benson and O'Reilly, 2009a, 2009b) can be divided into three sub-groups: residential tourists, rural idyll seekers, and bourgeois bohemians (2009a: 618). It is not only the sunny weather or the low cost of living that attracts these migrants but also the search for a more integrated community life, ecological setting or cultural excitement. Financially speaking, some of these migrants are able to keep their sources of income in their countries of origin. In doing so, they depend on internet and phone-based (self)employment, savings, property rental, or seasonal employment 'back home', many times in combination with small enterprises at the new haven. However, what mainly allows these migrants to enjoy an affluent lifestyle, compared to that of the local population, is the difference between the cost of living at their new destination and the value of their income and savings.

This particular mode of 'privileged mobility' (Croucher, 2012) is so special because it is based primarily on expanding the consumption force and enhances an existing value of income. In contrary, other forms of privileged mobility, like professional skilled migrants (Standing, 2009) or international entrepreneurs (Ong, 1999), are production (or commerce) oriented and are driven by an increase of income as a result of advanced and more resourceful mobilities. This important characteristic affects not only the way in which individuals perceive their movement in the international space, but also how nation-states 
accommodate these migrants within their borders. Such considerations vary largely also in the political status and requirements of the receiving states from the migrants.

Generally, production led migration introduced both economic and political challenges to the destination countries. Not only did it create problems to do with unemployment and welfare claims, but also introduced new modes of collective belonging away from the national affiliation. Diasporic communities joined local nonmigrant groups to demand collective recognition based on specific ethnic, racial, religious, cultural, sexual, class and/or cultural identities. This resulted with the development of identity roles within the state and outside it, as sub, supra-, or multi- national forms of belonging to mark a new stage where citizenship and nationality grew apart (Castles and Davidson, 2000, Isin and Turner, 2002, Ong, 2006). Despite the attempt to disconnect the territory bound nations from increased global migration and the emergence of new modes of citizenship, nation-states still play an important role in regulating migration and non-national claims for civil and political rights (Basch et al., 1994). A 'global mobility regime' is applied to classify individuals and groups according to perceived social risks and political threats (Shamir, 2005). In doing so, affluent states continuously introduce more rigid policies to 'battle' the expansion of immigration, yet show preference to desirable profiles (mostly related to social class or ethnic origin) above many others. This bureaucratic global regime of visas, residency permits and naturalisation schemes is imposed by affluent countries even on high profile migrants. This is done primarily to retain the state's sovereignty as a legitimate protector of its citizens' rights and privileges in comparison to foreigners.

Consumption migration, in contrast, is much more desirable for nation states, especially for financially disadvantaged ones, since the mobility of such migrants promises a flow of foreign capital into the country. Instead of benefiting from employment, these migrants expand their ability to consume thanks to attractive prices or availability of certain desired commodities and services, such as medical treatments, leisure and entertainment, or properties and housing. Falling into a highly appreciated category by the receiving states, and often mistaken as a form of tourism, lifestyle migration has demanded little regulation. Since the phenomenon usually consists of affluent individuals and families (certainly in relation to most locals) moving from the financially and politically 'less threatening' global North, it has escaped the policing discourse of migration control and limitation of movement (Oliver, 2011). On the contrary, some countries, like the United States or Mexico, have considered granting a special civil status of permanent residency to individuals who own a property in the country and hold proof of sufficient funds to allow them living without the need for employment in the local market (Ibid.). Other countries, like India (Korpela, 2009), shed an eye on visas and other forms of migration control to encourage such a profitable mobility due to its spending force. 
However, consumption migration does introduce some challenges to the hosting states. Similarly to tourism, it might cause economic dependence, cultural alienation or environmental deterioration. In more apparent cases, lifestyle migration might influence the local market and the raise of prices, to affect mainly the purchase power of the less affluent segments of local societies (Jackiewicz and Craine, 2010, Visser, 2003). It is also clear that granting privileged rights to consumption migrants and limiting the mobility of other production migrants only enhanced the global class inequality in relation to the freedom of movement. Yet other aspects in which lifestyle migration influences local populations have been understudied. Some studies did mention cultural isolation and class distinctions of migrants from local populations (Oliver and O'Rielly, 2010). However, political issues related to granting privileged rights to non-citizen migrants have received little attention in academic research, especially in the ways this might influence the relation between the state and its local populations.

When highly influenced by the neoliberal market and transnational mobilities, nation-states may choose to compromise in migration enforcement and allow migrant groups to acquire economic and civil rights (even, at times, with special privileges) without holding an official political status in return for economic growth (see the example of the Cayman Islands, Amit, 2001). Questioning economic and civil rights of migrants, especially in cases where there is little clarity regarding the political status that they hold, must shed some light not only on the relations between the nation-state and privileged foreigners but also the way such policies influence marginalised local minorities and their political struggles. These issues become even more prominent in remote or frontier areas where governmental control is weak. There, the empowerment of migrant communities may challenge the maintenance of national identity, or even state institutions, and create alternative social boundaries in relation to the local populations.

The case of lifestyle migration in South Sinai, Egypt, will provide an example to how such questions are manifested within a dependant state. It will show the different dilemmas of the Egyptian government that has been seeking to encourage foreign investments, on the one hand, and to hold on to promoting nationalisation, on the other. First, I will shortly present the historical context in which lifestyle migration emerged in South Sinai. The following section will discuss the process of nationalisation in Sinai and its influence on the indigenous Bedouins. Later on, I will examine how granting rights to real estate ownership for lifestyle migrants served government interests, yet ended up with the urgency to create civic spaces where civil membership is based primarily on financial participation. Finally, the paper will conclude with the dilemmas that the permissive financial policies create in South Sinai, and address the way they question the legitimacy and efficiency of the modern notion-state. 


\section{Tourism Development in the Egyptian Frontier}

Without underestimating the impact of the recent revolutionary developments in Egypt on Sinai since the 25th of January 2011, the region for its own geo-political reasons has been in a state of instability during most of Egypt's modern history. The underdevelopment of the Sinai Peninsula and the absence of civil infrastructure have been perpetuated by the long political dispute over the region between Egypt and Israel. Three wars between the two neighbouring countries (in 1956, 1967 and 1973) took place on its ground during the second half of the $20^{\text {th }}$ century, resulting in continuous border shifts and 15 years of Israeli military occupation. A certain measure of political stability was reached only after the Camp David Accords in 1979 and the complete withdrawal of Israeli troops from the Sinai Peninsula by 1982.

However, even after the national borders were finally drawn up, Sinai was still far from being fully incorporated into the Egyptian state. This situation was exacerbated by Israel's conditions to limit the number of the Egyptian security forces that could be stationed in the vast peninsula at the distant frontier. These strict conditions became a major challenge to the Egyptian government, just when former president Hosni Mubarak came to office in 1981, in the effort to nationalise the newly reclaimed land and establish civil and modern administration there. In its civilising mission, the Egyptian government had to come up with urgent political and financial plans to control the area and develop it.

The solution appeared on the Southern edge of the peninsula with its sandy coast on the Red Sea, where the Egyptian government established tourism driven economy. It gave Egypt the opportunity to develop its newlyregained lands and attract foreign investments while avoiding a political confrontation with Israel. Yet tourism in South Sinai was hardly an Egyptian invention. It already started during the Israeli occupation in the 1970s, when few small hostels and tourist facilities were built near Israeli settlements to accommodate the growing number of visitors from mainland Israel and Europe (Lavie, 1990).

Throughout the 1980s the Egyptian government continued to develop the tourism potential in the area and assuaged fears of Israeli reoccupation. Significant tourism plans were implemented only in 1994, when the Egyptian government and international aid agencies came up with extensive projects to develop the Gulf of Aqaba. These programs, some of which continued until recent years, aimed to expand holiday resorts and to create protected environmental areas along the coast (Sowers, 2007). South Sinai was designed for mass international tourism, providing a wide variety of vacations all year round, from backpackers' huts and budget hostels to luxury beach resorts, including fivestar hotels, gourmet restaurants and casinos. The demand was so great that South Sinai became the third busiest spot for one of Egypt's most profitable national industries. 
Nationalising the Land and its 'Uncivilised' Population

Aside from its financial benefits, tourism also became a political tool in the hand of the government to swiftly accommodate a vast internal migration from the mainland to help nationalising the peninsula. Furthermore, lifestyle migration and tourism related investments in real estate helped to appropriate the territory to fit the global neo-liberal market and put the modern civil foundations on Sinai's ground. However, these two policies had a major impact on the Bedouin indigenous population, who to a limited extent did benefit financially but suffered largely from losing its nomadic lifestyle and its distinct cultural features (Gilbert, 2011).

The first act of nationalisation made by the Egyptian state after it reclaimed the Sinai Peninsula was to declare all its territory as a state owned land (mulkiya khasa lil-dawla), which could be used, leased, or sold to any interested parties only by the state according to Law 143 of 1981. The introduction of exclusive individual rights over land had severe effects on the indigenous Bedouins, who already have experienced continuous political instability and thus largely relied on tribal organisation and its customary law (qanun al'urf or al-qawanin al-urfiyya) for self-governance. According to these customs, territories are mainly divided between tribes, with collective rights over the use of land and its resources within the geographical borders of each tribe. Any member of the tribe is able to claim wade' yad (literally hand hold) of an empty plot of land and cultivate it, but this does not entail exclusive individual ownership of the plot. Furthermore, one individual, or nuclear family, can also claim rights over more than a single plot of land and then move periodically between them. However, if the land is appropriated but has not been used for long time, any other member of the tribe may claim it for cultivation (Baily, 2009: 263-268).

Upon the declaration of the Egyptian state ownership of Sinai's land, the Bedouins 'moral claim' of wad' yad over their lands was only partially recognised by the state (a similar case from Egypt's northwestern Mediterranean coast is discussed by Cole and Altorki, 1998: 202). It allowed such claims to be implemented individually only for plots that were actually inhabited, forcing the Bedouins to choose ownership of only a single plot per an individual or a nuclear family. If this modern rational was not enough to harm the interpersonal relations and the collective rights to the land, the Bedouins were required to still pay a fee to register their lands at the civil local authority. However, the official registry of land served as a political tool for discrimination. Even in the rare cases when Bedouins were able to provide the necessary funds for registry, the state preferred to sell mainly to Egyptians or foreign individuals and companies.

Thus, many Bedouins, from the tribes Mzeina and Tarabin whose territories are located on the Red Sea coast, had to give up nomadic life and settle down in (or around) the coastal tourist towns. Even without official state registry, some affluent Bedouins were able to develop the land and 
profit from its revenues, but many others, lacking financial means and fearful of confiscation felt compelled to sell their rights over prime land for a pittance. They would then resettle on the outskirts of the tourist towns, 'encroaching' their own tribal territory and reclaiming their rights on 'state owned' desert lands. This vicious circle of claiming, disclaiming and reclaiming lands, labelled the Sinai Bedouins as disobedient, criminal and civically irresponsible population; a threat to the sovereignty of the modern nation state. Moreover, the designation of the Arabic word badawi (p. badu) for Bedouin, that shares an etymological relation with the words bedaya (beginning) and beda' $i$ (primeval, inchoate or primitive). Similar to imperial English, its often used antonym is hadari (p. hadar $^{2}$ meaning civil or modern, which is a semantic relative of hadara (culture or civilisation) mutahadder (cultured or civilised). This can help to explain the perception of the Bedouins as 'uncivilised' both by the Egyptian urban elite and by the state. Such images of the Sinai Bedouins only added up to their accusations with weak national loyalty and incompetence in the job market, pushing them to the fringes of the tourism market to work informally as independent taxi drivers and as tourist guides in the desert (Aziz, 2000), or to involvement in illegal activities across the national border (Hobbs, 1998, Marx, 2008).

Other, more 'civilised', populations were encouraged to take over the lion share of the tourism market. From the early 1980s, employment in tourism and in public services was exclusively reserved for unquestionable Egyptian citizens who came from the urban mainland. The governmental intention was to employ unskilled male workers in hotels, restaurants and souvenir shops. In addition, a smaller group of state officials, middle class professionals and entrepreneurs was encouraged to relocate to Sinai, either for career advancement or simply to escape the overcrowded cities. Many of these men eventually chose to stay in the region and brought their families. This mobility was of such a great national importance that a special presidential project was declared in the early 2000 s to resettle three million Egyptians from the mainland to Sinai (both North and South) by the year $2017,{ }^{3}$ offering special tax reductions for investors and help in loans for those who decided to relocate.

The government welcomed the emergence of Egyptian middle and upper classes; composed of modern, urban, wealthy, and above all nationalist citizens. However, local resources were not enough to achieve these governmental far reaching plans, external involvement was still necessary. It was in this complex social space that lifestyle migration in South Sinai emerged.

\section{Liberalisation and the Non-National 'Civilised' Migrants}

It was mainly the extensive tourists' interest in the marine life of the Red Sea that stimulated the appearance of residential foreign communities in South Sinai. In the absence of locals trained in scuba diving, European and other foreign professionals were eager to service the growing demand. The first wave in the mid 1980s of these 
skilled and adventurous professionals gradually opened the door to other various tourist residents and lifestyle migrant groups. In the beginning these explorers included mainly youngsters in their 20s and 30s. Some were long duration backpackers and others were small scale entrepreneurs or semiskilled professionals who maintained a seasonal migration during the winter months. Towards the 1990 s, with the expansion of the tourism market, many foreign residents started spending larger periods of the year in Sinai. New lifestyle migrant populations, including mid-aged individuals, couples and even families with children, set their primary home in the area. These, along with a significant number of European women who established romantic relationships and marriages with local men (Jacobs, 2010, Karkabi, 2011), began prominently contributing to the local economy and the raising real estate market.

Towards the first decade of the new millennium, the two main tourist towns in South Sinai, Sharm El-Sheikh and Dahab, looked like one big construction site. Private houses with courtyards, accommodating Western Europeans (mainly from Britain, Germany, The Netherlands and Italy), were soon followed by the construction of multilevel apartment buildings to house new clientele from East European countries (mainly Russia, Ukraine and Poland). Within a short period of less than 20 years land prices in the coastal towns have increased phenomenally. People who bought lots for construction in the 1990s directly from the Bedouins paid around 35 to 50 Egyptian Pounds (about 6-8 USD) per square meter, whereas in recent years land for sale is very rare to find and instead real estate agencies offer houses and apartments for sale for no less than 200,000 to 500,000 Egyptian Pounds (about 33,000-82,000 USD). ${ }^{4}$

Quantifying the numbers of tourist residents in South Sinai is very difficult as there are no concrete statistics or a definition for who should be counted. ${ }^{5}$ In any case, the phenomenon was large enough for the Egyptian government to consider regulation of this mobility, especially in relation to rights over real estate and civil status. When the foreigners started extensively purchasing land during the 1990s, the state issued laws to limit the size of land (up to $4000 \mathrm{~m}^{2}$ ) and number of properties (up to two) that were allowed for non-Egyptians to purchase for private residential purposes (Law 230 of 1996). However, the legal mismatch between the civil and the Bedouin qanun al-'urf regarding land tenure, along with the difference in the way the Bedouins and the state divided the plots, resulted in various cases of disputes. These disputes were mostly within the Bedouin community or with the state, yet sometimes they also involved third parties who bought a property and found themselves caught in between the two different legal systems. ${ }^{6}$

The situation became so elusive that the state had to intervene again. As a preliminary step, in 2005, the prime minister issued a decree (No. 548) declaring that real estate registry is prohibited for non-Egyptians at Sharm El-Sheikh, offering instead only a leasehold tenure up to 99 years with legal rights only to usufruct the land. Two years later, another decree (No. 350 of 2007) was introduced to 
expand the previous prohibition to the whole range of the Sinai Peninsula and to include also foreign companies. Although the government's motive in issuing this alternative leasing scheme was to reduce foreign involvement in nationally sensitive regions, anomalies in the decree allowed some lawyers to promise their clients the possibility to draw up contracts in which properties would be sold from one beneficiary to another without losing the right for a full 99 years of lease. ${ }^{7}$

Amidst this permissive climate, more Europeans (both from the West and the East of the continent) continued to relocate to South Sinai. They would depend on personal savings, inheritances or property rentals back in the countries of origin. To complement their income and make use of their time, some found waged employment in giving services to international tourists, others established niche business to serve both local and foreign residents (like bakeries for western pastries, bars or even boutique cloths' shops) and there were also those who indulged completely into early retirement to enjoy their time in making art, sports or friends.

Lifestyle migrants in Sinai are hardly considered affluent in their home countries, where they usually have struggled with tenure and outgoings that would define them as working-class or middle-class. Moving to Egypt, a much cheaper country than any of the equivalent European options (like France, Spain or Portugal), many of the Sinai European migrants had a great financial advancement simply by maintaining their income in one part of the world and reducing their expenses by moving to another. They became part of the financial elite in the host country, able to employ locals and to hold a strong bargaining position in claiming privileged rights. This perhaps can explain why lifestyle migration in South Sinai has been expanding despite the fragility of the tourism industry in the Middle East (Hazbun, 2008) and in Sinai in particular (Uriely et al., 2007), as well as amidst the local and regional violence and political instability.

Administratively speaking, this form of migration became possible as a result of a particular interest of the Egyptian state, which saw financial and political benefits in the foreign residents. Long term tourist visas of up to one year (with flexible extensions) were, and still are, issued to citizens of wealthy countries, who's Europeaness was perceived as a guarantee for 'civilisation'. This same policy also allows Europeans exceptional financial rights that would normally require an official residency status which the Egyptian government was not willing to issue. Despite the fact that many of these residential tourists own businesses, are informally employed (and are thus exempt from paying taxes), and/or own private properties in Sinai, their political rights in Egypt are limited and their legal status remains very delicate.

However, in an attempt to reconcile nationalisation and the region's economic development, Mubarak's government introduced an extreme liberal and market oriented approach to South Sinai. It has granted its tourist towns a special administrative semiautonomous status that resembles some of the European pre-modern city-states. These 'civilised' cities, as distinct from the 'savage' and the 
'uncultured' territories, offered legal protection to individual residents and professional collectives, like the guilds, living in their borders (Black 2001). Similarly to some of these pre-modern city-states, especially the 'consumption cities' (Weber, 1958), civic participation in South Sinai touristic towns is based primarily on economic membership. Thus, Sharm el-Sheikh became Mubarak's personal pride of which he could boast around the world about its great financial achievements. It was soon named Egypt's 'Peace City', where regional and international political summits were held. However, in order to maintain this image, Egyptian failures were swept under the carpet. The government continued to pursue its policy pushing the Bedouins to the fringes of the tourist towns and the job market, and with time also restrict the flow of Egyptian workers. Using the excuse to control terrorism, checkpoints were established on every highway crossroad and at the entrance to each town in South Sinai. Furthermore, Sharm el-Sheikh took the lead in becoming an actual luxury gated city by constructing a perimeter fence intended to surround the entire city and repel all undesirable 'invaders' ${ }^{8}$

In a situation where the only way to provide civil services to the growing migrant communities is through the commercial sphere, civil inclusion in South Sinai became increasingly predicated on social class. European and Egyptian local elites not only came together in business partnerships but also had to create new solutions to their ever-increasing daily requirements which the state was unable to provide. The most tangible example of this is elementary education. Whereas ordinary Egyptian and some Bedouin families send their children to government public schools, the elite has set up their own private, multi-lingual schools that offer their offspring higher standards of education. Other examples include in-house sports and cultural activities provided by hotels, both for children and adults, private medical services, and private commercial media. In the daily reality of these tourist city-states, two parallel civil systems operate. One is a mal functioning public governmental system that provides basic needs to its political members. It operates on the bases of national equality, but is considered inferior by Sinai's population. The other is private commercial system that offers high quality services to international members regardless of their nationality. This financial membership offers freedom of participation in the civil life beyond the national boundaries, yet it creates obvious inequalities of social class and eventually also of ethnicity.

The true sense of the civil society in South Sinai became that of an exclusive bourgeois domain (according to the Marxist understanding), where competitive individual participation in the commercial market grants more rights than any collective affiliation. Therefore, whereas the formal national citizenship should have secured privileges to locals over foreigners, the informal but real sense of economic citizenship, supported by the nation-state, allows privileges to foreigners over locals. Although the elite class included both Egyptians and Europeans, it was clear that the great majority of Europeans who settled down in South Sinai were financially 
capable to operate in the private commercial sphere. The fact that they had a much higher value of their income or savings coming from Europe could almost automatically qualify them into this class. Those Europeans who came 'broke' to Sinai to look for employment could not last for very long in a reality of unstable job market and available cheap local labour. Such a social casting of Europeans, although in the disguise of the liberal approach of free individual rights based on a universal criteria, not only creates a regime of global inequalities but raisescompelling questions about claiming collective differential rights by sub-national minorities. While Europeans, as a distinct group, are perceived to receive privileged rights, indigenous Bedouins felt encouraged to raise similar collective demands from the state. In such a situation not only did the state allow individual inequality but also a categorical difference to operate based on tribal affiliation and financial qualifications, creating a threat to the national unity of equal citizens and the state as their legitimate governing authority.

Lifestyle Claims: Property Rights, Communal Affiliations and the Modern Nation State

In relation to lifestyle migration and property ownership in South Sinai, during the presidential period of Mubarak, the Egyptian governmental policies formed a situation in which the foundations of the modern nationstate are challenged. Allowing a civil space to operate primarily based on a financial liberal membership has created a misbalance between the two contradictory concepts of the modern state; that of national community with equal rights and that of free economic rights to individual property. This violation of the sensitive equilibrium operating within the frames of the nation-state, between communal equality and individual freedom, gave legitimacy for the Bedouin tribes in Sinai to demand collective rights and cultural recognition apart from national belonging.

The inherent tension between the idea of free property and that of equal membership was historically resolved by two main approaches to define the membership of national citizens. The liberals used the dimension of property to reduce the tension at the individual level. In this sense citizenship rights are naturally and equally granted to members of a nation-state for all individuals to be able to freely practice their economic rights. The communitarians formed their point of view around the idea of community; citizenship rights should be acquired based on membership in a national collective community where each member not only has equal rights but also equal obligations to the collective. Despite the theoretical differences in settling the tension between freedom-equality (propertycommunity, individual-collective), both approaches agreed that the modern nation-state is the largest unit for a political community to grant civil and political rights to its members regardless of their biological, cultural, or economic differences (Chatterjee, 2004, Massad, 2001).

Upon reclaiming the Sinai Peninsula, it was only expected from the 
Egyptian government to nationalise the newly regained land and its population for integration into the Egyptian state collective. However, this attempt has been facing great difficulties for evident reasons having to do with the violation of the basic legitimacy of the modern nation-state. On the one hand, nationalising the peninsula's lands to create a regime of individual ownership has caused a great alienation among the indigenous Bedouin community, which still held greater affiliation to its tribal organisation than to the modern state. On the other hand, the government introduced a globalised free economy to fit a neo-liberal market, where non-national foreigners are allowed to hold property rights. Such contradicting policies had slowed down nationalisation in Sinai and instead allowed tribal sub-national and financial supra-national communities to practise civil participation by claiming differential collective recognition away from national affiliation. The legitimacy of the nation-state as the protector of equal rights to its citizens had little meaning, as a basic provider of social services of low quality, in a territory where tribal hierarchies and class hierarchies were much more significant in people's daily lives. Therefore, it is no wonder that the Bedouin and the European children barely went to the governmental public school system. This only reproduced inequality on the global scale, where children of the elites receive a high quality of education in a private system, whereas many of the Bedouin children cannot even read and write. Moreover, on the level of political economy, the government allowed foreigners to enjoy privileged financial rights and better access to civil participation and, in contrast, it disinherited indigenous populations from their collective resources with providing them with an equal civil membership in the national community.

Lifestyle migration from the global North to the South introduces new dynamics of claiming and practising civil rights. Such migrant populations participate in civil life in the host country based on distinct forms of a globally reaching citizenship that stems from affiliation to affluent donor countries taking advantage of the international dependency system. It is thus important to understand this global hierarchy not only on a state to state level but also on the individual level. Questions of political and civil rights should be examined more closely through North-South consumption led migration, such as lifestyle migration, in contrast to the focus on SouthNorth production led migration. Furthermore, it is important to point out and question the mechanism in which liberal agendas are imposed and acted upon in financial, political and cultural spheres within financially disadvantaged destinations of lifestyle migration, such as Egypt.

However, states, even when compelled to apply permissive liberal policies to encourage the flow of foreign investment, still hold an influential role in shaping emerging migrant spaces and determining the future of the populations within its borders. South Sinai's lifestyle migrants are not the first group of foreigners in Egyptian history to become a financial pillar while retaining an ambiguous political status. Marius Deeb (1978) writes about the 'local foreign minorities': 
European (British, French, Italians, and Greeks) and non-European (Armenians and Jews) who allied with the colonial powers that operated during monarchic Egypt. They were investors, traders, and entrepreneurs who helped to establish the modern Egyptian economy during the $19^{\text {th }}$ and the first half of the $20^{\text {th }}$ centuries. The process of decolonisation during the $1950 \mathrm{~s}$ resulted in the disappearance of this foreign elite, who either fled the country or obtained the Egyptian citizenship and assimilated into the larger Christian Coptic minority. Although present conditions in Sinai are different from the period of Egyptian independence, this historical precedent may serve as a reminder about the vague future of lifestyle migrants in South Sinai, under the conditional state in which they do not hold any political rights.

\section{New Government, Old Challenges: South Sinai after the Revolution}

After the revolution broke out in January 2011, the Bedouins launched an upraising of their own demanding social justice from the Egyptian government. In order not to harm their source of livelihood from tourism, South Sinai Bedouins (unlike their neighbours in the North) have been more wary about using violence as a mode of protest against the state. Nevertheless, throughout the past two years, frequent kidnappings of international tourists and Egyptian officials were used to negotiate the release of Bedouin prisoners held in Egyptian jails for both political and criminal activities. ${ }^{9}$ In other direct protests, properties were violently squatted in the claim of indigenous rights of ownership. ${ }^{10}$

Since Mubarak's close associates, primarily former military high-ranked generals, were the main beneficiaries from the nationalisation schemes in Sinai, the interim government controlled by the Security Council of Armed Forces (SCAF) played a major role in further suppressing Bedouin political claims. In order to protect their own financial interest in the Red Sea tourism market, members of the SCAF dismissed the Bedouin protests altogether by falsely linking them to extreme political Islam (such as global Jihad or even Al-Qa'eda). ${ }^{11}$ Instead, the Bedouins' recent violent actions should be primarily perceived as part of a bigger political struggle in which they are claiming rights from the Egyptian government. This campaign, however, reflects an internal dilemma; between calling for national inclusion as equal citizens and claiming collective cultural rights over lands and properties. Following the first option would force the Bedouins into individualised life and integration into the modern state, thus giving up their 'urfi legal system and gradually losing their particular culture and lifestyle. The second option is even harder to apply, since a political precedent in which the state would recognise differential collective rights of Bedouins in Sinai may raise similar demands among other minority communities (such as Copts or Bedouins in other parts of Egypt), putting the currently fragile 'national unity' at risk.

Meanwhile, as if the challenges of the newly elected government with land ownership and citizenship rights to the South Sinai Bedouin population 
are not enough, a very recent decree (No. 14 of 2012) has caused a great panic. In the sections addressing specifically the Sinai Peninsula, the decree states that all Egyptian citizens holding a second foreign nationality or those who are descendants to at least one non-Egyptian parent, including all the non-Egyptian citizens, must sell their rights to property (being private or commercial) within 6 months. Otherwise the government will confiscate such properties and pay compensation to its legal claimants according to an estimate of an appointed appraiser. A few weeks after September 2012, when media reports ${ }^{12}$ caused a public uproar among much of the upper class Egyptian citizens and foreigners, the Prime Minister Hisham Qandeel had to assure the South Sinai residents during an interview at AlJazeera that the decree will not be enacted retrospectively, affecting only property agreements conducted after the issue of the decree.

This very recent episode has only proved that the government, especially in the light of the unresolved conflict with the Bedouin population, is not yet interested in confronting the South Sinai upper classes, either Egyptians with dual nationalities or the remaining European residents, with limitations to their privileges. For the governmental concerns, these upper classes, as 'not Egyptian enough' as they may be considered, would still serve as a valuable partner in keeping the tourism industry from crashing and also as a neutral social buffer amidst the tension with the Bedouin population. However, it is clear that issues of property and citizenship rights are far from a resolution and it is difficult to foresee how the recent developments would affect the future of inter-community relations in South Sinai, as well as the dynamics visà-vis the new regime in the country. The newly elected government is facing difficult decisions regarding the lifestyle it is interested to shape in South Sinai. Either way, it will have to address internal crucial political issues to do with differential collective rights to Bedouins, equal individual rights to satisfy its electorate and clarify the legal definition of lifestyle migrants in Egypt.

\section{Notes}

${ }^{1}$ See the recent article by Mai Serhan in Jadaliyya, 'The Politics of Image: The Bedouins of South Sinai': http://www. jadaliyya.com/pages/index/6101/thepolitics-of-image the-bedouins-of-southsinai (Published on 26.6.2012)

2 Though, at times, also the word madani (urban), from madina (city), is also employed in this context.

${ }^{3}$ Egyptian Environmental Affairs Agency (EEAA), SEAM Project (2003) 'South Sinai Development Plan', South Sinai Governorate. See: http://st-katherine. net/downloads/Development\%20Profile. pdf

${ }^{4}$ See a typical real estate website: http:// dahab-realestate.com/

${ }_{5}^{5}$ Rough estimates reached few thousands in the years before the revolution broke out.

${ }^{6}$ See: Rashed, Dina, 'Gold Rush', $A l$ Ahram Weekly 3/9/2003 (http://weekly. ahram.org.eg/2003/653/feature.htm). Loza, Pierro, 'Laden Claims', Al-Ahram Weekly 15/12/2005 (http://weekly.ahram. org.eg/2005/773/feature.htm)

7 See: http://www.propertycommunity. com/forum/egypt-property/6847-legalquestions-answers-egyptian-lawyer.html 
(from July 2007).

8 Ibrahim, Amira. 'Sharm Fence, Sharp Controversy', Al-Ahram Weekly 9/11/2005: http://weekly.ahram.org.eg/2005/767/eg7. htm.

9 See: Harriet Sherwood, 14.2.2012, 'Sinai Explodes into Violence After Years of Chronic Poverty and Alienation', The Guardian: http://www.guardian. co.uk/world/2012/feb/14/s in a iviolence-poverty-alienation-bedouinegypt?INTCMP=SRCH. Akbar Ahmed and Harrison Akins, 15.2.2012, 'No Spring for Egypt's Bedouin', Al-Jazeera: http://www.aljazeera.com/indepth/ opinion/2012/02/201221413149992744. html.

10 See: Jack Shenker, 24.1.2012, 'Bedouin Tribesmen Storm Egyptian Tourism resort', The Guardian: http:// www.guardian.co.uk/world/2012/jan/24/ bedouin-tribesmen-egyptian-tourist-resort

11 Some of the claims about Jihad existence in Sinai might be true regarding the northern part of the peninsula, but cannot be generalised about all Bedouins involved in political protest in the region.

12 See: Nabil Shawkat, 20.11.2012, 'The tragic fate of Sinai's dual-nationals', AlAhram in English: http://english.ahram. org.eg/News/58680.aspx

\section{References}

Amit, V. (2001) 'A Clash of Vulnerabilities: Citizenship, Labor, and Expatriacy in the Cayman Islands'. American Ethnologist, 28 (3): 574-594.

Aziz, H. (2000) 'Employment in a Bedouin Community: The Case of the Town of Dahab in South Sinai'. Nomadic Peoples, 4(2): 28-47.

Bailey, C. (2009) Bedouin Law from Sinai and the Negev: Justice without

Government. New Haven and London: Yale University Press.

Basch L., Glick-Schiller N. and C. Szanton-Blanc (1994) Nations Unbound:

Transnational Projects, Postcolonial Predicaments and Deterritorialized Nation-

States. London: Routlage.

Benson, M. and K. O'Reilly (2009a) 'Migration and the Search for a Better Way of Life: A Critical Exploration of Lifestyle Migration'. The Sociological Review, 57(4): 608-625.

Benson, M. and K. O'Reilly (2009b) (eds.) Lifestyle Migration: Expectations, Aspirations and Experiences. Surry, UK: Ashgate.

Black, A. (2001). 'Concepts of Civil Society in pre-Modern Europe'. In Kaviraj, S. and S. Khilnani (eds.) Civil Society: History and Possibilities, pp. 33-39.

Cambridge: Cambridge University Press.

Böröcz, J. (1996) Leisure Migration: A Sociological Study on Tourism. Oxford:

Pergamon Press.

Castles, S. and A. Davidson (2000) Citizenship and Migration: Globalizations and the Politics of Belonging. New York: Palgrave.

Chatterjee, P. (2004) The Politics of the Governed: Reflections on Popular Politics in Most of the World. New York: Columbia University Press.

Cole, D. and S. Altorki (1998) Bedouin, Settlers, and Holiday-Makers: Egypt's

Changing Northwest Coast. Cairo: The American University in Cairo Press.

Croucher, S. (2012) 'Privileged Mobility in an Age of Globality'. Societies, 2: 1-13. 
Deeb, M. (1978) 'The Socioeconomic Role of the Local Foreign Minorities in Modern Egypt, 1805-1961'. International Journal of Middle East Studies, 9(1): 11-22.

Gilbert, H. (2011) “This is not Our Life, it's Just a Copy of Other People's': Bedu and the Price of 'Development' in South Sinai'. Nomadic Peoples, 15(2): 7-32. Hall, C and D. Muller (2004) Tourism, Mobility, and Second Homes: Between Elite Landscape and Common Ground. Clevedon, UK: Channel View Publications. Hazbun, W. (2008) Beaches, Ruins, Resorts: The Politics of Tourism in Arab World. Minneapolis, MN: University of Minnesota Press.

Hobbs, J. J. (1998). 'Troubling Fields: The Opium Poppy in Egypt'. The Geographical Review, 88(1): 64-79.

Isin, E. F. and B. S. Turner (2002) 'Citizenship Studies: an Introduction'. In: Isin, E. F. and B. S. Turner (eds.) Handbook of Citizenship Studies, pp. 1-10. London, Thousand Oaks, New Delhi: Sage Publications.

Jackiewicz, E. L. and J. Craine (2010) 'Destination Panama: An Examination of the Migration-Tourism-Foreign Investment Nexus'. Recreation and Society in Africa, Asia and Latin America, 1(1): http://www.criticalimprov.com/index.php/ rasaala/article/viewArticle/1498 (consulted 5.8.2012)

Jacobs, J. (2010) Sex, Tourism and the Postcolonial Encounter: Landscapes of Longing in Egypt. Surry, UK: Ashgate.

Lavie, S. (1990) The Poetics of Military Occupation: Mzeina Allegories of Bedouin Identity under Israeli and Egyptian Rule. Berkley, CA: University of California Press.

Loker-Murphy, L. and P. Pierce (1995) 'Young Budget Travelers: Backpackers in Australia'. Annals of Tourism Research, 22(4): 819-843.

Karkabi, N. (2011) 'Couples in the Global Margins: Sexuality and Marriage between Egyptian Men and Western Women in South Sinai'. Anthropology of the Middle East, 6(1): 79-97.

Korpela, M. (2009)'When a Trip to Adulthood becomes a Lifestyle: The Community of Westerners in Varanasi, India'. In: Benson, M. and K. O'Reilly (eds.), Lifestyle Migration: Expectations, Aspirations and Experiences, pp. 15-30. Aldreshot: Ashgate.

Marx, E. (2008) 'Hashish Smuggling by Bedouin in South Sinai'. Studies of Organized Crime, 7(1): 29-37.

Massad, J. (2001) Colonial Effects: The Making of National Identity in Jordan. New York: Columbia University Press.

Oliver, C. (2011) 'Lifestyle Migration'. In: Betts, A. (ed.) Global Migration Governance, pp. 133-152. Oxford: Oxford University Press.

Oliver, C. and K. O'Reilly (2010) 'A Bourdieusian Analysis of Class and Migration: Habitus and the Individualising Process'. Sociology, 44(1): 49-66. Ong, A. (2006) 'Mutations in Citizenship'. Theory, Culture and Society, 23(2-3): 499-505.

Ong, A. (1999) Flexible Citizenship: The Cultural Logics of Transnationality. Durham and London: Duke University Press.

Shamir, R. (2005) 'Without Borders? Notes on Globalization Mobility Regime'. 
Sociological Theory, 23(2): 197-217.

Sowers, J. (2007) 'Nature Reserves and the Authoritarian Rule in Egypt: Embedded Autonomy Revised'. Journal of Environment and Development, 16(4): 375-397.

Standing, G. (2009) Work after Globalization: Building Occupational Citizenship. Cheltenham: Edward Elgar Publishing.

Uriely, N., Maoz, D. and A. Reichel (2007) 'Rationalising Terror-Related Risks:

The Case of Israeli Tourists in Sinai'. International Journal of Tourism Research, 9(1): $1-8$.

Visser, G. (2003) 'Visible, yet Unknown: Reflections on Second-Home Development in South Africa'. Urban forum, 14(4): 379-307.

Warens, A. and A. Williams (2006) 'Older Migrants in Europe: A New Focus for Migration Studies'. Journal of Ethnic and Migration Studies, 32(8): 1257 - 1281. Weber, M. (1958) The City. Glencoe, IL: Free Press.

Williams, A. and C. Hall (2000) 'Tourism and Migration: New Relationships between Production and Consumption'. Tourism Geographies, 2(1): 5-27. 